\title{
Corynebacterium lubricantis sp. nov., isolated from a coolant lubricant
}

\author{
Peter Kämpfer, ${ }^{1}$ Nicole Lodders, ${ }^{1}$ Isabel Warfolomeow, ${ }^{2}$ Enevold Falsen ${ }^{3}$ \\ and Hans-Jürgen Busse ${ }^{4}$
}

Correspondence
Peter Kämpfer
peter.kaempfer@
umwelt.uni-giessen.de

The genus Corynebacterium currently comprises more than 80 species. The majority of the most recently described Corynebacterium species have been isolated from clinical specimens (e.g. Renaud et al., 2001, 2007; Yassin et al., 2002a, b, 2003) or animals (e.g. Fernández-Garayzábal et al., 1998, 2004; Goyache et al., 2003; Collins et al., 2001, 2004).

A study on the diversity of bacteria from coolant lubricants revealed the presence of some yellow-pigmented, rodshaped isolates that exhibited Gram-positive behaviour and fatty acid profiles consistent with their provisional

\section{Abbreviations: pNA, p-nitroanilide; pNP, p-nitrophenyl.}

The GenBank/EMBL/DDBJ accession numbers for the 16S rRNA gene

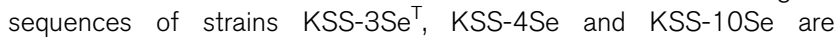
FM173119-FM173121, respectively.

An extended neighbour-joining tree and a comparison of biochemical characteristics of the novel species and related members of Corynebacterium are available as supplementary material with the online version of this paper. assignment to the genus Corynebacterium. Strains KSS$3 \mathrm{Se}^{\mathrm{T}}, \mathrm{KSS}-4 \mathrm{Se}$ and KSS-10Se were isolated on tryptone soy agar (TSA) at $25{ }^{\circ} \mathrm{C}$. The strains showed yellow colonies on this agar. Subcultivation was done on TSA at $28{ }^{\circ} \mathrm{C}$ for $48 \mathrm{~h}$. On this agar, the organisms were able to grow at 10$45{ }^{\circ} \mathrm{C}$, but not at 4 or $50{ }^{\circ} \mathrm{C}$. Growth at $25{ }^{\circ} \mathrm{C}$ was also observed on PYE agar ( $0.3 \%$ peptone from casein, $0.3 \%$ yeast extract, $1.5 \%$ agar, $\mathrm{pH} 7.2$ ), nutrient agar, MacConkey agar and R2A agar (all from Oxoid). Gramstaining was performed as described by Gerhardt et al. (1994) and the KOH-lysis test as described by Moaledji (1986). Cell morphology was observed under a Zeiss light microscope at $\times 1000$, with cells grown for 3 days at $28{ }^{\circ} \mathrm{C}$ on TSA. The strains showed a (weak) Gram-positive staining reaction and were not lysed in the $\mathrm{KOH}$ test, confirming the results from Gram staining.

The 16S rRNA genes of all three strains were analysed as described by Kämpfer et al. (2003). Multiple alignments and phylogenetic analysis were performed using the 
software MEGA version 3.1 (Kumar et al., 2004). The sequenced length of the 16S rRNA gene was $1379 \mathrm{bp}$ for strain KSS-3Se ${ }^{\mathrm{T}}, 1442$ bp for strain KSS-4Se and $1407 \mathrm{bp}$ for strain KSS-10Se. Nucleotide sequence comparisons of the three isolates showed only a few ( $<10$ positions) differences between the three isolates. Similarities were $99.7 \%$ between KSS-3S $\mathrm{e}^{\mathrm{T}}$ and KSS-4Se, $99.6 \%$ between

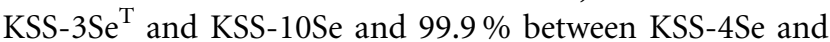
KSS-10Se. The sequence of strain KSS-3Se $\mathrm{e}^{\mathrm{T}}$ showed $97.6 \%$ similarity with that of Corynebacterium pilosum NCTC $11862^{\mathrm{T}}$. The similarity was lower than $97.0 \%$ compared with the sequences of strains of all other recognized Corynebacterium species. A tree based on the neighbourjoining method is shown in Fig. 1, and an extended tree is available as Supplementary Fig. S1 (available in IJSEM Online).

Analyses of cell-wall diamino acid, quinones, polar lipids and polyamines were done with biomass grown on PYE agar. Detection of the diagnostic cell-wall diamino acid was performed by the method of Schleifer (1985). In strain $\mathrm{KSS} 3 \mathrm{Se}^{\mathrm{T}}$, meso-diaminopimelic acid could be identified, which is characteristic for Corynebacterium species. Polar lipids and quinones were extracted and analysed as reported by Tindall (1990a, b), Altenburger et al. (1997) and Stolz et al. (2007). The quinone system of KSS-3Se ${ }^{\mathrm{T}}$ consisted of menaquinones MK- $9\left(\mathrm{H}_{2}\right), \mathrm{MK}-8\left(\mathrm{H}_{2}\right)$ and MK-7 $\left(\mathrm{H}_{2}\right)$ in the ratio $49: 30: 21$. A complex polar lipid profile was detected in KSS-3Se ${ }^{\mathrm{T}}$ (Fig. 2) consisting of the major compounds phosphatidylglycerol and an unknown, quite hydrophobic glycolipid GL5, moderate amounts of phosphatidylinositol, diphosphatidylglycerol, two unknown glycolipids (GL1, GL3), three unknown aminolipids (AL1, AL2, AL3) and an unknown polar lipid (L2) and minor amounts of unknown glycolipids GL2 and GL4, aminolipid AL4 and polar lipid L1. Phosphatidylinositol mannosides, reported to be present in several Corynebacter- ium species (Fudou et al., 2002; Yassin et al., 2003; Chen et al., 2004), could not be detected unambiguously. Polyamine analysis was carried out as described by Busse \& Auling (1988) and Altenburger et al. (1997) using the instrumentation described by Stolz et al. (2007). Strain KSS-3Se ${ }^{T}$ exhibited a polyamine pattern consisting of the major compounds spermidine $[0.47 \mu \mathrm{mol} \quad(\mathrm{g}$ dry weight $\left.)^{-1}\right]$ and spermine $\left[1.16 \mu \mathrm{mol}(\mathrm{g} \text { dry weight })^{-1}\right]$ and minor amounts of 1,3-diaminopropane [0.01 $\mu \mathrm{mol}(\mathrm{g}$ dry weight $\left.)^{-1}\right]$ and putrescine $[0.01 \mu \mathrm{mol}$ (g dry weight $)^{-1}$. This pattern, with rather low polyamine contents and dominated by spermidine and spermine, is in good agreement with those detected in other Corynebacterium species (Altenburger et al., 1997). The fatty acid profile of strain KSS-3Se ${ }^{\mathrm{T}}$ studied as described by Kämpfer \& Kroppenstedt (1996) is composed mainly of $\mathrm{C}_{16: 0}(40.8 \%), \mathrm{C}_{18: 1} \omega 9 c(35.6 \%)$ and 10 -methyl $\mathrm{C}_{18: 0}$ (tuberculostearic acid; 19.2\%), with smaller amounts of $\mathrm{C}_{12: 0}(0.5 \%), \mathrm{C}_{14: 0}(1.2 \%), \mathrm{C}_{16: 1} \omega 9 c(1.2 \%), \mathrm{C}_{17: 1} \omega 7 c$ $(1.0 \%)$ and $\mathrm{C}_{18: 0}(2.6 \%)$. It is slightly different from the profile of C. pilosum DSM $20521^{\mathrm{T}}$ (Table 1), which was studied concurrently.

Results of the physiological characterization are given in the species description and in Table 2. Methods used were described previously (Kämpfer et al., 1991). Further differentiating characters of the most similar Corynebacterium species (on the basis of $16 \mathrm{~S}$ rRNA gene sequence similarities) are given in Supplementary Table S1.

DNA-DNA hybridization experiments were performed with strains KSS-3Se ${ }^{\mathrm{T}}$ and C. pilosum DSM $20521^{\mathrm{T}}$. DNA isolation and DNA-DNA hybridization were done as described previously (Ziemke et al., 1998). Results of the DNA-DNA cross-hybridization yielded a relatedness of $22.9 \%$, whereas reciprocal hybridization resulted in a lower value of $20.4 \%$.

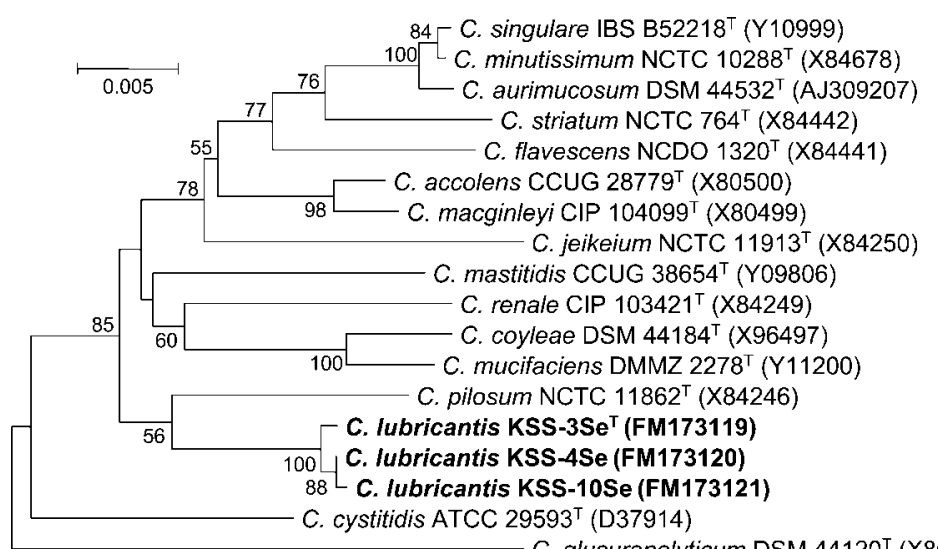

C. glucuronolyticum DSM $44120^{\top}$ (X86688)
Fig. 1. Phylogenetic analysis based on $16 \mathrm{~S}$ rRNA gene sequences from the most closely related Corynebacterium species available from the EMBL database (accession numbers in parentheses) showing the position of strains KSS-3Se ${ }^{\top}, \mathrm{KSS}-4 \mathrm{Se}$ and KSS-10Se. Multiple alignments, distance calculations (distance options according to the Kimura-2 model) and clustering with the neighbour-joining method were performed by using the software package MEGA version 3.1 (Kumar et al., 2004). Bootstrap values based on 1000 replications are listed as percentages at branching points. Bar, 0.005 nucleotide substitutions per nucleotide position. An extended neighbour-joining tree including a wider selection of reference sequences is available as Supplementary Fig. S1. 


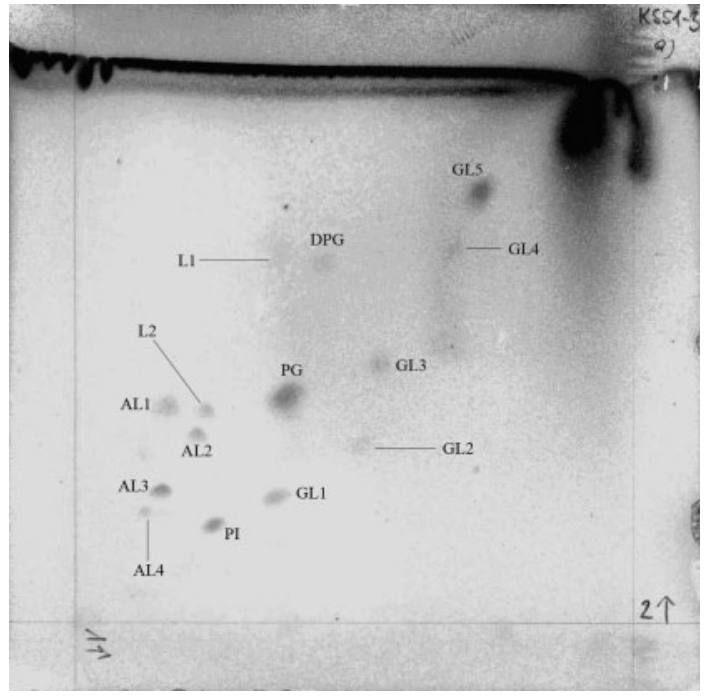

Fig. 2. Polar lipid profile of strain $\mathrm{KSS}-3 \mathrm{Se}^{\top}$ after two-dimensional TLC and detection with molybdatophosphoric acid. PG, Phosphatidylglycerol; DPG, diphosphatidylglycerol; PI, phosphatidylinositol; AL1-4, unknown aminolipids; L1-2, unknown polar lipids; GL1-5, unknown glycolipids.

From the results of $16 \mathrm{~S}$ rRNA gene sequencing, DNA-DNA hybridization data and phenotypic analyses (significantly smaller amounts of $\mathrm{C}_{18: 1} \omega 9 \mathrm{c}$ and differences in physiological/biochemical traits), it is evident that strain KSS$3 \mathrm{Se}^{\mathrm{T}}$ is different from $C$. pilosum and all other Corynebacterium species and, hence, a novel species of the genus Corynebacterium is proposed.

\section{Description of Corynebacterium Iubricantis sp. nov.}

Corynebacterium lubricantis [lu.bri.can'tis. L. v. lubricare to lubricate; N.L. n. lubricans -antis (from L. part. adj. lubricans) a lubricant; N.L. gen. n. lubricantis of/from a (coolant) lubricant].

Table 1. Cellular fatty acid contents of strains $K S S-3 \mathrm{Se}^{\top}$, KSS-4Se and KSS-10Se and C. pilosum DSM $20521^{\top}$

Values are percentages of total fatty acids; minor fatty acids $(<0.5 \%)$ are not shown. Results were obtained in this study. ND, Not detected.

\begin{tabular}{|lcc|}
\hline Fatty acid & $\begin{array}{c}\text { KSS-3Se }^{\mathrm{T}} \text {, KSS-4Se } \\
\text { and KSS-10Se }\end{array}$ & $\begin{array}{c}\text { C. pilosum } \\
\text { DSM 20521 }\end{array}$ \\
\hline $\mathrm{C}_{14: 0}$ & $0.9-1.8$ & $\mathrm{ND}$ \\
$\mathrm{C}_{16: 1} \omega 9 c$ & $1.0-2.8$ & 4.3 \\
$\mathrm{C}_{17: 1} \omega 7 c$ & $1.0-1.9$ & 1.3 \\
$\mathrm{C}_{16: 0}$ & $43.6-49.6$ & 42.9 \\
$\mathrm{C}_{18: 1} \omega 9 c$ & $31.6-45.3$ & 42.5 \\
$10-$ Methyl $\mathrm{C}_{18: 0}$ & $10.8-30.8$ & 7.3 \\
$\mathrm{C}_{18: 0}$ & $1.7-4.3$ & 1.0 \\
\hline
\end{tabular}

Table 2. Differentiating physiological/biochemical properties of the novel strains and C. pilosum DSM $20521^{\top}$

\begin{tabular}{|lcc|}
\hline Characteristic & $\begin{array}{c}\text { KSS-3Se }^{\mathrm{T}} \text {, KSS-4Se } \\
\text { and KSS-10Se }\end{array}$ & $\begin{array}{c}\text { C. pilosum } \\
\text { DSM 20521 }\end{array}$ \\
\hline Acid production from: & - & $+^{\text {T }}$ \\
Sucrose & - & $+^{*}$ \\
Mannose & - & + \\
Cellobiose & + & $-{ }^{*}$ \\
Aesculin hydrolysis & + & $+^{*}$ \\
Growth on MacConkey agar & - & $+^{*}$ \\
Nitrate reduction & - & \\
Urease activity & & \\
\hline
\end{tabular}

${ }^{\star}$ Result in congruence with results reported by Yanagawa \& Honda (1978) and Collins \& Cummins (1986).

Cells are non-motile, non-spore-forming rods (approx. $1 \mu \mathrm{m}$ long). Gram-positive, oxidase-negative, showing an oxidative metabolism. Good growth occurs on R2A agar, TSA, nutrient agar and MacConkey agar at $25-30{ }^{\circ} \mathrm{C}$. Yellow, translucent and shiny colonies with entire edges form within $24 \mathrm{~h}$, with a diameter of approximately $0.5 \mathrm{~mm}$. The lipid profile consists of the major compounds phosphatidylglycerol and an unknown glycolipid, moderate amounts of phosphatidylinositol, diphosphatidylglycerol, two unknown glycolipids, three unknown aminolipids and an unknown polar lipid and minor amounts of two glycolipids, an aminolipid and a polar lipid. Polyamines are present in small amounts; the major compounds are spermidine and spermine. The quinone system is composed of significant amounts of menaquinones MK-9 $\left(\mathrm{H}_{2}\right)$, MK- $8\left(\mathrm{H}_{2}\right)$ and MK- $7\left(\mathrm{H}_{2}\right)$. The characteristic peptidoglycan diamino acid is mesodiaminopimelic acid. The fatty acid profile contains large amounts of $\mathrm{C}_{16: 0}, \mathrm{C}_{18: 1} \omega 9 c$ and 10-methyl $\mathrm{C}_{18: 0}$. The novel species can be differentiated from C. pilosum through its fatty acid profile and by physiological tests (Tables 1 and 2 ). The following compounds are used as sole sources of carbon: D-fructose, D-glucose, acetate, fumarate and DLlactate on the basis of the method described by Kämpfer et al. (1991). The following compounds are not utilized: $N$ acetylgalactosamine, $\mathrm{N}$-acetylglucosamine, L-arabinose, Larbutin, cellobiose, D-galactose, maltose, D-mannose, Lrhamnose, D-ribose, salicin, trehalose, D-xylose, adipate, 2oxoglutarate, D-gluconate, melibiose, sucrose, adonitol, myo-inositol, maltitol, D-mannitol, D-sorbitol, propionate, cis- and trans-aconitate, 4-aminobutyrate, citrate, glutarate, DL-3-hydroxybutyrate, itaconate, L-malate, mesaconate, pyruvate, L-alanine, $\beta$-alanine, L-aspartate, L-leucine, $\mathrm{L}$ ornithine, L-proline, L-serine, putrescine, azelate, suberate, L-histidine, L-phenylalanine, L-serine, L-tryptophan, 3hydroxybenzoate and phenylacetate. Acid is produced from glucose and trehalose. No acids are produced from sucrose, D-mannitol, dulcitol, lactose, rhamnose, maltose, galactose, salicin, adonitol, inositol, sorbitol, L-arabinose, 
raffinose, D-xylose, trehalose, cellobiose, methyl D-glucoside, erythritol, melibiose, D-arabitol or D-mannose. $p$ Nitrophenyl (pNP) $\beta$-D-glucopyranoside, $\mathrm{pNP} \beta$-D-glucuronide, bis-pNP phosphate and bis-pNP phenylphosphonate are hydrolysed on the basis of the method described by Kämpfer et al. (1991). The following compounds are not hydrolysed: $\mathrm{pNP} \alpha$-D-glucopyranoside, $\mathrm{pNP} \beta$-D-galactopyranoside, pNP $\beta$-D-xylopyranoside, bis-pNP phosphorylcholine, L-alanine $p$-nitroanilide (pNA), L-proline pNA and $\gamma$-L-glutamate pNA.

The type strain is $\mathrm{KSS}-3 \mathrm{Se}^{\mathrm{T}}\left(=\mathrm{DSM} 45231^{\mathrm{T}}=\mathrm{CCUG}\right.$ $56567^{\mathrm{T}}=$ CCM $7546^{\mathrm{T}}$ ), isolated in Giessen, Germany, from a coolant lubricant. Strains KSS-4Se and KSS-10Se are additional strains of the species.

\section{Acknowledgements}

The study was supported by a grant to P.K. from the Berufsgenossenschaft Metall Nord Süd - BGM (formerly Berufsgenossenschaft Metall Süd).

\section{References}

Altenburger, P., Kämpfer, P., Akimov, V. N., Lubitz, W. \& Busse, H.-J. (1997). Polyamine distribution in actinomycetes with group $B$ peptidoglycan and species of the genera Brevibacterium, Corynebacterium, and Tsukamurella. Int J Syst Bacteriol 47, 270-277.

Busse, H.-J. \& Auling, G. (1988). Polyamine pattern as a chemotaxonomic marker within the Proteobacteria. Syst Appl Microbiol 11, 1-8.

Chen, H.-H., Li, W.-J., Tang, S.-K., Kroppenstedt, R. M., Stackebrandt, E., Xu, L.-H. \& Jiang, C.-L. (2004). Corynebacterium halotolerans sp. nov., isolated from saline soil in the west of China. Int J Syst Evol Microbiol 54, 779-782.

Collins, M. D. \& Cummins, C. S. (1986). Genus Corynebacterium Lehmann and Neumann 1986, 350 ${ }^{\mathrm{AL}}$. In Bergey's Manual of Systematic Bacteriology, vol. 2, pp. 1266-1283. Edited by P. H. A. Sneath, N. S. Mair, M. E. Sharpe \& J. G. Holt. Baltimore: Williams \& Wilkins.

Collins, M. D., Hoyles, L., Foster, G., Sjödén, B. \& Falsen, E. (2001). Corynebacterium capitovis sp. nov., from a sheep. Int J Syst Evol Microbiol 51, 857-860.

Collins, M. D., Hoyles, L., Foster, G. \& Falsen, E. (2004). Corynebacterium caspium sp. nov., from a Caspian seal (Phoca caspica). Int J Syst Evol Microbiol 54, 925-928.

Fernández-Garayzábal, J. F., Collins, M. D., Hutson, R. A., González, I., Fernández, E. \& Domínguez, L. (1998). Corynebacterium camporealensis sp. nov., associated with subclinical mastitis in sheep. Int J Syst Bacteriol 48, 463-468.

Fernández-Garayzábal, J. F., Vela, A. I., Egido, R., Hutson, R. A., Lanzarot, M. P., Fernández-García, M. \& Collins, M. D. (2004). Corynebacterium ciconiae sp. nov., isolated from the trachea of black storks (Ciconia nigra). Int J Syst Evol Microbiol 54, 2191-2195.

Fudou, R., Jojima, Y., Seto, A., Yamada, K., Kimura, E., Nakamatsu, T., Hirashi, A. \& Yamanaka, S. (2002). Corynebacterium efficiens sp. nov., a glutamic-acid-producing species from soil and vegetables. Int $J$ Syst Evol Microbiol 52, 1127-1131.
Gerhardt, P., Murray, R. G. E., Wood, W. A. \& Krieg, N. R. (editors) (1994). Methods for General and Molecular Bacteriology. Washington, DC: American Society for Microbiology.

Goyache, J., Ballesteros, C., Vela, A. I., Collins, M. D., Briones, V., Hutson, R. A., Potti, J., García-Borboroglu, P., Dominguez, L. \& Fernández-Garayzábal, J. F. (2003). Corynebacterium sphenisci sp. nov., isolated from wild penguins. Int J Syst Evol Microbiol 53, 10091012.

Kämpfer, P. \& Kroppenstedt, R. M. (1996). Numerical analysis of fatty acid patterns of coryneform bacteria and related taxa. Can J Microbiol 42, 989-1005.

Kämpfer, P., Steiof, M. \& Dott, W. (1991). Microbiological characterization of a fuel-oil contaminated site including numerical identification of heterotrophic water and soil bacteria. Microb Ecol 21, 227-251.

Kämpfer, P., Dreyer, U., Neef, A., Dott, W. \& Busse, H.-J. (2003). Chryseobacterium defluvii sp. nov., isolated from wastewater. Int J Syst Evol Microbiol 53, 93-97.

Kumar, S., Tamura, K. \& Nei, M. (2004). MEGA3: integrated software for molecular evolutionary genetics analysis and sequence alignment. Brief Bioinform 5, 150-163.

Moaledji, K. (1986). Comparison of Gram-staining and alternate methods, $\mathrm{KOH}$ test and aminopeptidase activity in aquatic bacteria: their application to numerical taxonomy. J Microbiol Methods 5, 303310.

Renaud, F. N. R., Aubel, D., Riegel, P., Meugnier, H. \& Bollet, C. (2001). Corynebacterium freneyi sp. nov., $\alpha$-glucosidase-positive strains related to Corynebacterium xerosis. Int J Syst Evol Microbiol 51, 1723-1728.

Renaud, F. N. R., Le Coustumier, A., Wilhelm, N., Aubel, D., Riegel, P., Bollet, C. \& Freney, J. (2007). Corynebacterium hansenii sp. nov., an $\alpha-$ glucosidase-negative bacterium related to Corynebacterium xerosis. Int J Syst Evol Microbiol 57, 1113-1116.

Schleifer, K. H. (1985). Analysis of the chemical composition and primary structure of murein. Methods Microbiol 18, 123-156.

Stolz, A., Busse, H.-J. \& Kämpfer, P. (2007). Pseudomonas knackmussii sp. nov. Int J Syst Evol Microbiol 57, 572-576.

Tindall, B. J. (1990a). Lipid composition of Halobacterium lacusprofundi. FEMS Microbiol Lett 66, 199-202.

Tindall, B. J. (1990b). A comparative study of the lipid composition of Halobacterium saccharovorum from various sources. Syst Appl Microbiol 13, 128-130.

Yanagawa, R. \& Honda, E. (1978). Corynebacterium pilosum and Corynebacterium cystitidis, two new species from cows. Int J Syst Bacteriol 28, 209-216.

Yassin, A. F., Steiner, U. \& Ludwig, W. (2002a). Corynebacterium aurimucosum sp. nov. and emended description of Corynebacterium minutissimum Collins and Jones (1983). Int J Syst Evol Microbiol 52, 1001-1005.

Yassin, A. F., Steiner, U. \& Ludwig, W. (2002b). Corynebacterium appendicis sp. nov. Int J Syst Evol Microbiol 52, 1165-1169.

Yassin, A. F., Kroppenstedt, R. M. \& Ludwig, W. (2003). Corynebacterium glaucum sp. nov. Int J Syst Evol Microbiol 53, 705709 .

Ziemke, F., Höfle, M. G., Lalucat, J. \& Rosselló-Mora, R. (1998). Reclassification of Shewanella putrefaciens Owen's genomic group II as Shewanella baltica sp. nov. Int J Syst Bacteriol 48, 179-186. 